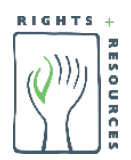

\title{
Status of Legal Recognition of Indigenous Peoples', Local Communities' and Afro-descendant Peoples' Rights to Carbon Stored in Tropical Lands and Forests
}

COMMUNITIES AND PROPOSED NATURE-BASED SOLUTIONS AT HIGH RISK DUE TO LACK OF RECOGNITION OF LAND AND CARBON RIGHTS OF INDIGENOUS PEOPLES, LOCAL COMMUNITIES, AND AFRO-DESCENDANT PEOPLES 


\section{Acknowledgments}

This report was authored by Katherine Lofts, Alain Frechette, and Kundan Kumar, with research and analysis by Fernanda Almeida, Ana Clara Simões, and Chloe Ginsburg. Andy White and Sebastien Jodoin provided content oversight and input.

We wish to extend our sincere thanks to Donna Lee and Charlotte Streck for their critical review. 
Status of Legal Recognition of Indigenous Peoples', Local Communities' and Afro-descendant Peoples' Rights to Carbon Stored in Tropical Lands and Forests

COMMUNITIES AND PROPOSED NATURE-BASED SOLUTIONS AT HIGH RISK DUE TO LACK OF RECOGNITION OF LAND AND CARBON RIGHTS OF INDIGENOUS PEOPLES, LOCAL COMMUNITIES, AND AFRO-DESCENDANT PEOPLES

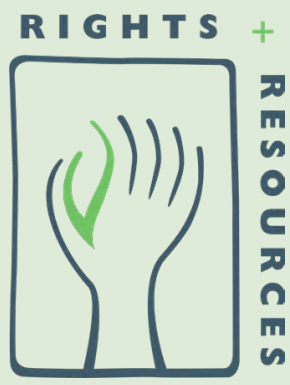

T he push for greater climate action is yielding unprecedented interest in nature-based solutions. Many countries are now poised to implement national programs to reduce emissions from deforestation and forest degradation (REDD+), ${ }^{1}$ as well as other land-based emissions reductions, removals, and avoidance initiatives using market instruments and resultsbased payment schemes. ${ }^{2}$ Meanwhile, as the world anticipates the finalization of the "rulebook" for international emissions trading under Article 6 of the Paris Agreement, countries and corporations are increasingly turning to voluntary markets, compliance mechanisms, and other "cooperative approaches" to help meet their emissions reduction targets ${ }^{3}$ and net-zero commitments. ${ }^{4}$ To further accelerate climate action, a global taskforce has been established to support the requisite scaling of voluntary carbon markets, ${ }^{5}$ and a growing number of countries are signing results-based payment agreements with dedicated climate financing instruments to account for both recent (e.g. Green Climate Fund) and forthcoming emission reductions (e.g. Carbon Fund). An ambitious publicprivate coalition (LEAF) has also been established with an aim to lower emissions by accelerating the market for forest carbon. Led by Norway, the United States, the United Kingdom, and top private sector actors such as Amazon, Bayer, and Unilever, the LEAF Coalition has an initial mobilization goal of at least \$1 billion to pay for jurisdictional REDD+ credits issued by the Architecture for REDD+ Transactions (ART) from tropical and subtropical forest countries.

To date, most of these interventions have unfolded in developing countries that include some of the poorest and most biodiverse regions of the world. More importantly, most of the lands and territories targeted for greenhouse gas (GHG) mitigation action overlap with areas customarily held by Indigenous Peoples, ${ }^{6}$ local communities, ${ }^{7}$ and Afro-descendant Peoples. ${ }^{8}$ However, just about half of the areas held by communities have yet to be legally recognized by governments, ${ }^{9}$ and where land rights are acknowledged, rights to carbon and tradeable emission reductions are seldom explicitly defined.

Given that communities hold customary rights to at least half of the world's land area and thus a significant proportion of the terrestrial carbon sink, failure to adequately recognize their rights and role in the realization of global climate ambitions poses fundamental risks for communities, investors, and governments alike.

This study reviews the status of the legal recognition of the rights of Indigenous Peoples, local communities, and Afro-descendant Peoples to the carbon in their lands and territories across 31 countries in Africa, Asia, and Latin America. ${ }^{10}$ Together, these countries hold almost 70 percent of the world's tropical forests ${ }^{11}$ and represent at least 62 percent of the total feasible natural climate solution potential identified by McKinsey et al. (2021), ${ }^{12}$ and thus the bulk of nature-based emissions reductions and carbon offset opportunities in tropical and subtropical forest countries. ${ }^{13}$ 


\section{Key Findings}

1. Few countries explicitly recognize communities' rights to carbon in their customary lands and forests. Even where community carbon rights can be inferred through existing laws, the nature and extent of such rights are subject to interpretation, and thus vulnerable to be claimed by state actors (see Box 2).

- Only 3 of the 31 countries studied explicitly recognize community rights to carbon on lands owned by or designated for communities (Ethiopia, Peru, Republic of Congo). However, in two of these countries (Ethiopia, Republic of Congo) the extent of lands currently owned by or designated for communities is negligible, thus undermining the legal and practical value of associated carbon rights.

- 3 countries (Brazil, Colombia, Costa Rica) tie carbon rights to land or forest ownership (whether public, private, or collective), which include lands legally owned by Indigenous Peoples, local communities, and Afro-descendant Peoples, thereby establishing their ownership of the carbon in their lands.

- 7 other countries (Bhutan, Fiji, Nepal, Nicaragua, Tanzania, Vietnam, Zambia) have ambiguous legal frameworks that could be interpreted to recognize community carbon rights.

2. Across the set of reviewed countries, only half of the total area traditionally held by Indigenous Peoples, local communities, and Afro-descendant Peoples is legally recognized, ${ }^{14}$ placing their customary land and carbon rights at risk of capture by states or other legal entities. Where defined, rights to carbon tend to be tied to existing land and forest rights (10 out of 16 countries that define carbon rights). Failure to legally recognize customary land rights thus undermines the formal recognition of communities' carbon rights and local incentives to support nature-based climate initiatives. The situation is far worse in Africa and Asia, where 77.0 and 84.4 percent, respectively of the lands held by communities lack legal recognition.

3. Despite more than a decade of investment in REDD+ readiness, only a handful of countries have established legal frameworks to regulate carbon-linked transactions, indicating that the majority of the countries assessed are ill-prepared to implement jurisdictional REDD+ approaches.

- Only 4 out of 31 countries (Colombia, Costa Rica, Peru, Republic of Congo) have enacted laws or regulations that define: (i) carbon credits; (ii) who owns them; (iii) the entity responsible for issuing and validating them; and (iv) how these are to be traded and registered in the country. Six (6) other countries have partially done so (Brazil, Côte d'Ivoire, Democratic Republic of Congo, Indonesia, Mexico, Vietnam).

4. Few countries have designed and operationalized the mechanisms that define how carbon and non-carbon benefits will be shared, as required by jurisdictional REDD+ approaches. Inadequate attention to benefit-sharing directly compromises countries' commitments to pursue actions on the basis of equity and in the context of sustainable development and poverty eradication. ${ }^{15}$

- Only 5 countries (Costa Rica, Indonesia, Mexico, Philippines, and Vietnam) have designed benefit-sharing mechanisms, and only one of those could be verified as being partially operational (Vietnam).

5. Little more than half of the countries in the study have developed feedback and grievance redress mechanisms to support engagement in REDD+, protect communities, and ensure fair, transparent, and robust transactions.

- Only 2 of the 17 countries that developed feedback and grievance redress mechanisms have operationalized them (Costa Rica and Mexico).

6. While many voluntary carbon certification standards include provisions relating to human rights and the recognition of communities' land tenure and resource rights, engagement and participation, benefit sharing, and channels for feedback and grievance redress, they largely fail to provide robust and effective mechanisms for monitoring, reporting, and verifying these elements.

- Only 2 of the 6 voluntary standards reviewed include requirements for the establishment of baselines for community wellbeing, along with impact monitoring and reporting on the basis of substantive indicators. 
Part 2 examines the lack of recognition of the rights of Indigenous Peoples, local communities, and Afro-descendant Peoples to the carbon in their customary lands and forests. Part 3 describes the magnitude of the lands and territories claimed by communities across the world and the extent to which communities' formal rights (of varying strengths) have and have not been recognized. Part 4 reviews the status of legal and regulatory frameworks to support carbon-linked transactions, including benefit-sharing mechanisms and feedback and grievance redress mechanisms, while Part 5 analyzes a selection of voluntary certification standards to determine the extent to which these standards provide effective safeguards to mitigate the risks faced by communities in the context of nature-based solutions. The report concludes by examining the implications of its key findings for policy makers and governments.

\section{Communities' rights to carbon}

Although the term 'carbon rights' has been used to describe a number of different tradeable GHG rights, ${ }^{16}$ it can generally be defined as "the right to benefit from sequestered carbon and/or reduced greenhouse gas emissions."17 In the context of land use and forestry activities, carbon rights arise in one of two ways, flowing either from ownership of the biomass or land undergoing conservation or restoration activities, or from control of an activity that leads to a reduction in deforestation or an enhancement in forest carbon stocks. ${ }^{18}$ As nature-based solutions aim to render carbon as a tradeable asset, the recognition and enforcement of communities' rights to carbon can provide an important safeguard against predatory land and carbon grabs, increased conflict, and unsustainable climate mitigation.

Table 1: Definition and ownership of carbon rights across study countries

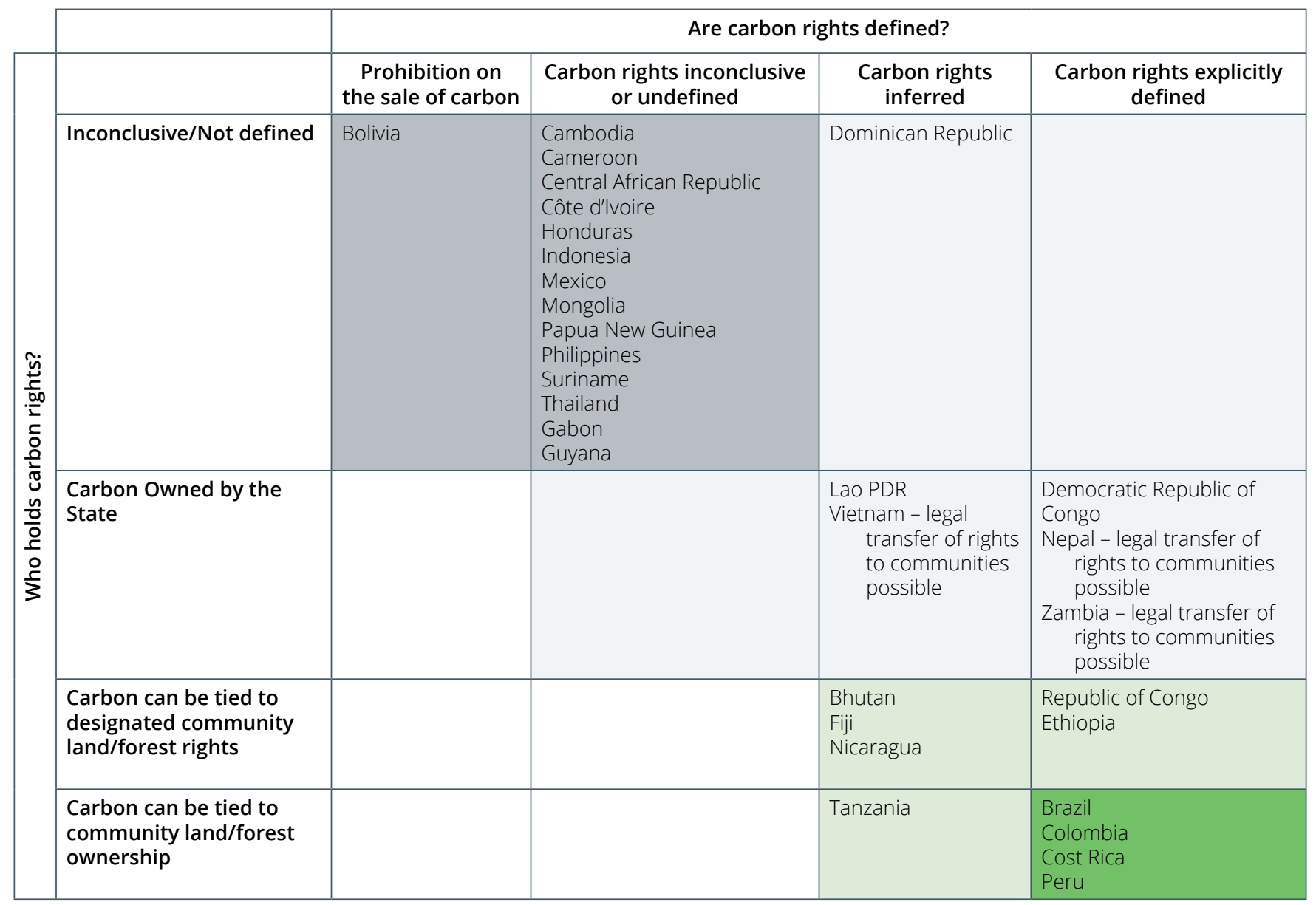


Despite the surge in interest in nature-based solutions, few countries explicitly recognize communities' rights to carbon in the customary lands and forests where many of the proposed GHG mitigation interventions will take place.

Of the 31 countries studied, only 3 (Ethiopia, Peru, and Republic of Congo) explicitly recognize community rights to carbon in lands owned by or designated for communities. Of these countries, only Peru has legally recognized a significant percentage of community-held lands (34.8\% of the country area ${ }^{19}$ ). By contrast, the extent of legally recognized community-held lands in Ethiopia and Republic of Congo is negligible, thus undermining the legal and practical value of community carbon rights in these countries.

In a further three countries (Brazil, Colombia, and Costa Rica), carbon rights are tied to land or forest ownership (whether public, private, or collective), which includes lands legally owned by Indigenous Peoples, local communities, and Afro-descendant Peoples, thereby establishing their ownership of the carbon in their lands. Seven other countries (Bhutan, Fiji, Nepal, Nicaragua, Tanzania, Vietnam, and Zambia) have legal frameworks that could be interpreted to recognize community rights to carbon. In the remaining 18 countries, carbon rights are either undefined, inconclusive, or are held by the State, with no opportunity for their transfer to communities.

Even where existing laws and regulations are relatively clear, the jurisprudence interpreting these provisions in the context of climate-related measures is nascent in most countries. Although projectlevel experimentation has resulted in some positive experiences (see Box 1), the shift towards jurisdictional approaches and crediting schemes is likely to further incentivize government capture of emission reduction credits, as the case of Brazil demonstrates (see Box 2). Critically, clearly defined

\section{Box 2: Community Carbon Rights in Brazil}

In Brazil, carbon rights are tied to forest rights and not to land rights. ${ }^{26}$ States and the federal government have concurrent jurisdiction to legislate on forests, and states may exercise full legislative authority in this regard where no federal law on general rules exists (Article 24 of the Brazilian Constitution). Carbon, as an environmental service (Article 41 (I)(A) Brazilian Forestry Code), also falls within the jurisdiction of states. The states of Amapá, Maranhão, and Tocantins have therefore asserted jurisdiction over the reduction of emissions from deforestation and forest degradation as a public service, interpreting the law to imply that title to "carbon credits" is attributable to the state. ${ }^{27}$ This interpretation poses a serious risk to the recognition of land rights and the right to self-determination of Indigenous Peoples, local communities, and Afro-descendant Peoples if states implement carbon projects in forests located on communities' lands without their free, prior and informed consent, and without the proper development and implementation of a Safeguard Information System (SISREDD+). These risks are a major concern in Amapá, Maranhão, and Tocantins, where $8-9 \%$ of the land area is classified as Indigenous Lands, ${ }^{28}$ and where land grabbing and human rights violations are already prevalent. ${ }^{29}$ 
carbon rights, tied to land or forest ownership, are insufficient in and of themselves, to ensure fair and equitable outcomes if states fail to legally recognize the customary rights of communities, continuing the inequalities and power imbalances that drive dispossession and concentration of land ownership. ${ }^{20}$

\section{Legal recognition of community-held lands and territories}

Across the set of reviewed countries, only half of the total area traditionally held by Indigenous Peoples, local communities, and Afro-descendant Peoples is legally recognized. ${ }^{30}$ Because rights to carbon tend to be tied to existing land and forest rights (10 out of the 16 reviewed countries that define carbon rights), failure to recognize customary land rights risks undermining communities' rights to carbon and support for nature-based solutions.

\section{Table 2: Legal recognition of community lands}

\begin{tabular}{|c|c|c|c|}
\hline Country & $\begin{array}{l}\text { Percent of country area where } \\
\text { rights of Indigenous peoples, } \\
\text { local communities, and Afro- } \\
\text { descendants are legally recognized }\end{array}$ & $\begin{array}{l}\text { Percent of country area where } \\
\text { rights of Indigenous peoples, local } \\
\text { communities, and Afro-descendants } \\
\text { are not legally recognized }\end{array}$ & $\begin{array}{l}\text { Total percent of land held } \\
\text { by Indigenous peoples, } \\
\text { local communities, and } \\
\text { Afro-descendants }\end{array}$ \\
\hline Cameroon & $9.00 \%$ & $72.00 \%$ & $81.00 \%$ \\
\hline Central African Republic & $0.00 \%$ & $81.40 \%$ & $81.40 \%$ \\
\hline Côte d'Ivoire & $0.50 \%$ & $86.70 \%$ & $87.20 \%$ \\
\hline Democratic Republic of Congo & $0.53 \%$ & $86.71 \%$ & $87.23 \%$ \\
\hline Ethiopia & Not available & Not available & Not available \\
\hline Gabon & $0.30 \%$ & $84.30 \%$ & $84.60 \%$ \\
\hline Republic of Congo & $1.30 \%$ & $84.90 \%$ & $86.70 \%$ \\
\hline Tanzania & $75.10 \%$ & $23.10 \%$ & $98.20 \%$ \\
\hline Zambia & $52.70 \%$ & $41.30 \%$ & $94.00 \%$ \\
\hline Bhutan & Not available & Not available & Not available \\
\hline Cambodia & $3.30 \%$ & $1.90 \%$ & $5.30 \%$ \\
\hline Fiji & Not available & Not available & Not available \\
\hline Indonesia & $0.40 \%$ & $22.10 \%$ & $22.50 \%$ \\
\hline Lao PDR & $0.10 \%$ & $21.70 \%$ & $21.80 \%$ \\
\hline Mongolia & Not available & Not available & Not available \\
\hline Nepal & $14.40 \%$ & $32.30 \%$ & $46.70 \%$ \\
\hline Papua New Guinea & Not available & Not available & Not available \\
\hline Philippines & $21.30 \%$ & $14.40 \%$ & $35.80 \%$ \\
\hline Thailand & $0.90 \%$ & $3.10 \%$ & $4.10 \%$ \\
\hline Vietnam & Not available & Not available & Not available \\
\hline Bolivia & $36.40 \%$ & $15.60 \%$ & $51.90 \%$ \\
\hline Brazil & $23.00 \%$ & $2.30 \%$ & $25.20 \%$ \\
\hline Colombia & $33.90 \%$ & $4.30 \%$ & $38.20 \%$ \\
\hline Costa Rica & $6.40 \%$ & $15.70 \%$ & $22.10 \%$ \\
\hline Dominican Republic & Not available & Not available & Not available \\
\hline Guyana & $19.30 \%$ & $60.70 \%$ & $80 \%$ \\
\hline Honduras & Not available & Not available & Not available \\
\hline Mexico & $52.00 \%$ & $0.50 \%$ & $52.50 \%$ \\
\hline Nicaragua & Not available & Not available & Not available \\
\hline Peru & $34.80 \%$ & $21.00 \%$ & $55.80 \%$ \\
\hline Suriname & $0.00 \%$ & $67.40 \%$ & $67.40 \%$ \\
\hline
\end{tabular}


Even in countries with laws and regulations that would otherwise support community-based tenure rights, ${ }^{31}$ most of the lands and forests targeted for nature-based greenhouse gas removals and offsets are located in areas where the customary rights of communities have yet to be recognized by the state. ${ }^{32}$

Moreover, while many countries have included the clarification of tenure rights for Indigenous and local communities as a component of their national REDD+ strategies, they have not always followed through with reforms. For example, in the Democratic Republic of Congo (DRC), which is the 7th most forested country in the world, a total of 86.7 percent of community-held lands and territories is not legally recognized, despite legislation securing community tenure to forests. ${ }^{33}$ Although the DRC's Emission Reductions Program Document emphasizes the recognition and strengthening of local communities' and Indigenous Pygmy Peoples' legal, customary and user rights over land, territories and resources, as of 2020, land-tenure reforms had not been completed and "efforts to address land-tenure insecurity remain limited." 34

Failure to legally recognize and secure community lands and associated carbon rights presents a significant hurdle to the realization of sustainable nature-based solutions. In addition to the fact that legally-recognized community lands store more carbon, produce lower emissions, and have significantly lower deforestation rates than lands owned by other actors, ${ }^{35}$ jurisdictional approaches cannot realistically be implemented without the full and effective engagement and cooperation of affected communities. With the growing potential for results-based payments and emission reductions via voluntary markets, countries that have yet to legally recognize community tenure rights will face increasing incentives to withhold legislative reforms in a bid to capture associated rents. Unless prevented from doing so through stricter application of international law and best practice principles for the recognition of community rights to land, due process, compensation, selfdetermination, and the exercise of free, prior and informed consent in all climate-related actions and investments, Indigenous Peoples, local communities, and Afro-descendant Peoples run the risk of further marginalization, injustice, and exposure to conflict.

24 of the countries covered in this analysis were considering draft laws and regulations relating to the trade in carbon and/or carbon rights at the time of writing. ${ }^{39}$ If passed, some of these new instruments may serve to strengthen community land and forest rights, but many are expected to further exacerbate communities' struggles for legal recognition and protection.

\section{Legal Frameworks and Safeguards}

Despite more than a decade of readiness investments, study results show that many countries lack the legal and regulatory frameworks needed to support carbon-linked transactions. And similarly, benefit sharing and grievance redress mechanisms have either yet to be fully defined or made operational in most of the reviewed countries. Considering that the majority of countries targeted for emission reductions and offsets suffer from both weak internal governance and limited accountability and transparency, failure to ensure compliance at entry could create substantial risks for communities and investors alike.

RIGHTS + RESOURCES INITIATIVE 


\section{(a) Legal Frameworks}

Only four out of the 31 countries assessed (Colombia, Costa Rica, Peru, and Republic of Congo) have enacted laws or regulations that define: (i) what carbon credits are; (ii) who owns them; (iii) the entity responsible for issuing and validating them; and (iv) how these are to be traded and registered in the country. Six other countries have done so partially (Brazil, Côte d'Ivoire, Democratic Republic of Congo, Indonesia, Mexico, and Vietnam).

Table 3: Legal frameworks to support carbon-linked transactions

\begin{tabular}{|c|c|c|c|c|c|}
\hline Country & $\begin{array}{l}\text { Laws for } \\
\text { securing } \\
\text { community } \\
\text { tenure to } \\
\text { forests? }\end{array}$ & $\begin{array}{l}\text { Established a } \\
\text { national legal } \\
\text { framework } \\
\text { for carbon } \\
\text { trade? }\end{array}$ & $\begin{array}{l}\text { Defined carbon } \\
\text { rights? }\end{array}$ & $\begin{array}{l}\text { Are carbon rights } \\
\text { linked to tenure? }\end{array}$ & $\begin{array}{c}\text { Do communities have carbon } \\
\text { rights? }\end{array}$ \\
\hline Cameroon & Yes & No & $\begin{array}{l}\text { Inconclusive or } \\
\text { undefined }\end{array}$ & $\begin{array}{l}\text { Inconclusive or } \\
\text { undefined }\end{array}$ & $\begin{array}{l}\text { Carbon rights inconclusive or } \\
\text { undefined }\end{array}$ \\
\hline $\begin{array}{l}\text { Central African } \\
\text { Republic }\end{array}$ & Yes & No & $\begin{array}{l}\text { Inconclusive or } \\
\text { undefined }\end{array}$ & $\begin{array}{l}\text { Inconclusive or } \\
\text { undefined }\end{array}$ & $\begin{array}{c}\text { Carbon rights inconclusive or } \\
\text { undefined }\end{array}$ \\
\hline Côte d'Ivoire & Yes & Partial & $\begin{array}{l}\text { Inconclusive or } \\
\text { undefined }\end{array}$ & $\begin{array}{l}\text { Inconclusive or } \\
\text { undefined }\end{array}$ & $\begin{array}{c}\text { Carbon rights inconclusive or } \\
\text { undefined }\end{array}$ \\
\hline $\begin{array}{l}\text { Democratic } \\
\text { Republic of Congo }\end{array}$ & Yes & Partial & $\begin{array}{l}\text { Defined by specific } \\
\text { law }\end{array}$ & $\begin{array}{l}\text { Carbon as public } \\
\text { property }\end{array}$ & Carbon rights owned by the state \\
\hline Ethiopia & Yes & No & $\begin{array}{c}\text { Defined by specific } \\
\text { law }\end{array}$ & Tied to forest rights & $\begin{array}{l}\text { Explicit recognition of community } \\
\text { rights to carbon }\end{array}$ \\
\hline Gabon & Yes & No & $\begin{array}{l}\text { Inconclusive or } \\
\text { undefined }\end{array}$ & $\begin{array}{l}\text { Carbon as public } \\
\text { property }\end{array}$ & $\begin{array}{c}\text { Carbon rights inconclusive or } \\
\text { undefined }\end{array}$ \\
\hline Republic of Congo & Yes & Yes & $\begin{array}{l}\text { Defined by specific } \\
\text { law }\end{array}$ & Tied to forest rights & $\begin{array}{l}\text { Explicit recognition of community } \\
\text { rights to carbon }\end{array}$ \\
\hline Tanzania & Yes & No & $\begin{array}{c}\text { Defined through } \\
\text { the interpretation of } \\
\text { other laws }\end{array}$ & Tied to forest rights & $\begin{array}{l}\text { Ambiguous legal framework that } \\
\text { could be interpreted to recognize } \\
\text { community carbon rights }\end{array}$ \\
\hline Zambia & Yes & No & $\begin{array}{c}\text { Defined by specific } \\
\text { law }\end{array}$ & $\begin{array}{c}\text { Carbon as public } \\
\text { property }\end{array}$ & $\begin{array}{l}\text { Ambiguous legal framework that } \\
\text { could be interpreted to recognize } \\
\text { community carbon rights }\end{array}$ \\
\hline Bhutan & Yes & No & $\begin{array}{c}\text { Defined through } \\
\text { the interpretation of } \\
\text { other laws }\end{array}$ & $\begin{array}{l}\text { Tied to the right to } \\
\text { land }\end{array}$ & $\begin{array}{l}\text { Ambiguous legal framework that } \\
\text { could be interpreted to recognize } \\
\text { community carbon rights }\end{array}$ \\
\hline Cambodia & Yes & No & $\begin{array}{l}\text { Inconclusive or } \\
\text { undefined }\end{array}$ & $\begin{array}{l}\text { Inconclusive or } \\
\text { undefined }\end{array}$ & $\begin{array}{c}\text { Carbon rights inconclusive or } \\
\text { undefined }\end{array}$ \\
\hline Fiji & Yes & No & $\begin{array}{c}\text { Defined through } \\
\text { the interpretation of } \\
\text { other laws }\end{array}$ & $\begin{array}{l}\text { Tied to the right to } \\
\text { land }\end{array}$ & $\begin{array}{l}\text { Ambiguous legal framework that } \\
\text { could be interpreted to recognize } \\
\text { community carbon rights }\end{array}$ \\
\hline Indonesia & Yes & Partial & $\begin{array}{l}\text { Inconclusive or } \\
\text { undefined }\end{array}$ & $\begin{array}{l}\text { Inconclusive or } \\
\text { undefined }\end{array}$ & $\begin{array}{c}\text { Carbon rights inconclusive or } \\
\text { undefined }\end{array}$ \\
\hline Lao PDR & Yes & No & $\begin{array}{c}\text { Defined through } \\
\text { the interpretation of } \\
\text { other laws }\end{array}$ & $\begin{array}{c}\text { Carbon as public } \\
\text { property }\end{array}$ & Carbon rights owned by the state \\
\hline Mongolia & Yes & No & $\begin{array}{l}\text { Inconclusive or } \\
\text { undefined }\end{array}$ & $\begin{array}{l}\text { Inconclusive or } \\
\text { undefined }\end{array}$ & $\begin{array}{l}\text { Carbon rights inconclusive or } \\
\text { undefined }\end{array}$ \\
\hline Nepal & Yes & No & $\begin{array}{c}\text { Defined by specific } \\
\text { law }\end{array}$ & $\begin{array}{c}\text { Carbon as public } \\
\text { property }\end{array}$ & $\begin{array}{l}\text { Ambiguous legal framework that } \\
\text { could be interpreted to recognize } \\
\text { community carbon rights }\end{array}$ \\
\hline $\begin{array}{l}\text { Papua New } \\
\text { Guinea }\end{array}$ & Yes & No & $\begin{array}{l}\text { Inconclusive or } \\
\text { undefined }\end{array}$ & $\begin{array}{l}\text { Inconclusive or } \\
\text { undefined }\end{array}$ & $\begin{array}{l}\text { Carbon rights inconclusive or } \\
\text { undefined }\end{array}$ \\
\hline Philippines & Yes & No & $\begin{array}{l}\text { Inconclusive or } \\
\text { undefined }\end{array}$ & $\begin{array}{l}\text { Inconclusive or } \\
\text { undefined }\end{array}$ & $\begin{array}{c}\text { Carbon rights inconclusive or } \\
\text { undefined }\end{array}$ \\
\hline Thailand & Yes & No & $\begin{array}{l}\text { Inconclusive or } \\
\text { undefined }\end{array}$ & Tied to forest rights & $\begin{array}{c}\text { Carbon rights inconclusive or } \\
\text { undefined }\end{array}$ \\
\hline
\end{tabular}




\begin{tabular}{|c|c|c|c|c|c|}
\hline Country & $\begin{array}{l}\text { Laws for } \\
\text { securing } \\
\text { community } \\
\text { tenure to } \\
\text { forests? }\end{array}$ & $\begin{array}{l}\text { Established a } \\
\text { national legal } \\
\text { framework } \\
\text { for carbon } \\
\text { trade? }\end{array}$ & $\begin{array}{l}\text { Defined carbon } \\
\text { rights? }\end{array}$ & $\begin{array}{l}\text { Are carbon rights } \\
\text { linked to tenure? }\end{array}$ & $\begin{array}{c}\text { Do communities have carbon } \\
\text { rights? }\end{array}$ \\
\hline Vietnam & Yes & Partial & $\begin{array}{c}\text { Defined through } \\
\text { the interpretation of } \\
\text { other laws }\end{array}$ & $\begin{array}{l}\text { Carbon as public } \\
\text { property }\end{array}$ & $\begin{array}{l}\text { Ambiguous legal framework that } \\
\text { could be interpreted to recognize } \\
\text { community carbon rights }\end{array}$ \\
\hline Bolivia & Yes & No & $\begin{array}{l}\text { Inconclusive or } \\
\text { undefined }\end{array}$ & $\begin{array}{l}\text { Inconclusive or } \\
\text { undefined }\end{array}$ & Prohibition on sale of carbon \\
\hline Brazil & Yes & Partial & $\begin{array}{l}\text { Defined by specific } \\
\text { law }\end{array}$ & Tied to forest rights & $\begin{array}{l}\text { Carbon rights to land / forest } \\
\text { ownership, which includes lands } \\
\text { legally owned by communities }\end{array}$ \\
\hline Colombia & Yes & Yes & $\begin{array}{l}\text { Defined by specific } \\
\text { law }\end{array}$ & $\begin{array}{l}\text { Tied to the right to } \\
\text { land }\end{array}$ & $\begin{array}{l}\text { Carbon rights to land / forest } \\
\text { ownership, which includes lands } \\
\text { legally owned by communities }\end{array}$ \\
\hline Costa Rica & Yes & Yes & $\begin{array}{l}\text { Defined by specific } \\
\text { law }\end{array}$ & $\begin{array}{l}\text { Tied to the right to } \\
\text { land }\end{array}$ & $\begin{array}{l}\text { Carbon rights to land / forest } \\
\text { ownership, which includes lands } \\
\text { legally owned by communities }\end{array}$ \\
\hline $\begin{array}{l}\text { Dominican } \\
\text { Republic }\end{array}$ & No & No & $\begin{array}{c}\text { Defined through } \\
\text { the interpretation of } \\
\text { other laws }\end{array}$ & $\begin{array}{l}\text { Tied to the right to } \\
\text { land }\end{array}$ & $\begin{array}{l}\text { Carbon rights inferred but ownership } \\
\text { inconclusive / not defined }\end{array}$ \\
\hline Guyana & Yes & No & $\begin{array}{l}\text { Inconclusive or } \\
\text { undefined }\end{array}$ & $\begin{array}{l}\text { Tied to land and } \\
\text { forest rights }\end{array}$ & $\begin{array}{c}\text { Carbon rights inconclusive or } \\
\text { undefined }\end{array}$ \\
\hline Honduras & Yes & No & $\begin{array}{l}\text { Inconclusive or } \\
\text { undefined }\end{array}$ & $\begin{array}{l}\text { Inconclusive or } \\
\text { undefined }\end{array}$ & $\begin{array}{l}\text { Carbon rights inconclusive or } \\
\text { undefined }\end{array}$ \\
\hline Mexico & Yes & Partial & $\begin{array}{l}\text { Inconclusive or } \\
\text { undefined }\end{array}$ & $\begin{array}{l}\text { Inconclusive or } \\
\text { undefined }\end{array}$ & $\begin{array}{l}\text { Carbon rights inconclusive or } \\
\text { undefined }\end{array}$ \\
\hline Nicaragua & Yes & No & $\begin{array}{l}\text { Defined through } \\
\text { the interpretation of } \\
\text { other laws }\end{array}$ & $\begin{array}{l}\text { Tied to the right to } \\
\text { land }\end{array}$ & $\begin{array}{l}\text { Ambiguous legal framework that } \\
\text { could be interpreted to recognize } \\
\text { community carbon rights }\end{array}$ \\
\hline Peru & Yes & Yes & $\begin{array}{c}\text { Defined by specific } \\
\text { law }\end{array}$ & $\begin{array}{l}\text { Tied to the right to } \\
\text { land }\end{array}$ & $\begin{array}{l}\text { Explicit recognition of community } \\
\text { rights to carbon }\end{array}$ \\
\hline Suriname & Yes & No & $\begin{array}{l}\text { Inconclusive or } \\
\text { undefined }\end{array}$ & $\begin{array}{l}\text { Inconclusive or } \\
\text { undefined }\end{array}$ & $\begin{array}{c}\text { Carbon rights inconclusive or } \\
\text { undefined }\end{array}$ \\
\hline
\end{tabular}

\section{(b) Benefit-Sharing and Grievance Redress}

Effective implementation of transparent and equitable benefit-sharing mechanisms is vital to ensuring that Indigenous Peoples, local communities, and Afro-descendant Peoples are recognized and rewarded for their contributions towards forest protection, conservation and restoration. Yet countries consistently lag in developing and operationalizing legally-sanctioned frameworks that define how carbon and non-carbon benefits will be shared, as required by jurisdictional REDD+ approaches. To date, only five of the 31 countries assessed (Costa Rica, Indonesia, Mexico, Philippines, and Vietnam) have fully designed benefit-sharing mechanisms, and only one of these (Vietnam) could be verified as partially operational - an assessment that remains unchanged since 2018, when the results of a similar analysis were published. ${ }^{40}$

Feedback and grievance redress mechanisms (FGRMs) are another essential safeguard for communities to address both actual and potential concerns about the intended or unintended impacts of a project or program. ${ }^{41}$ Though integral to REDD+ readiness requirements, ${ }^{42}$ little more than half of the countries assessed (17 out of 31) had fully designed FGRMs by the end of 2020, only two had operationalized their approach, ${ }^{43}$ and only one had developed a distinct legal structure, separate from existing legal judicial systems. ${ }^{44}$ The latter characteristic is significant because even though the integration of FGRMs into existing frameworks can have certain advantages, they seldom meet the criteria of accessibility, legitimacy, and predictability required under UN-REDD and FCPF guidance. ${ }^{45}$ Moreover, even when fully operationalized, the usefulness of FGRMs is likely to be 
undermined if communities' customary land rights and rights to free, prior and informed consent are not fully recognized.

Table 4: Benefit-sharing and grievance redress mechanisms

\begin{tabular}{|c|c|c|c|c|}
\hline Country & $\begin{array}{c}\text { Benefit sharing } \\
\text { mechanism designed? }\end{array}$ & $\begin{array}{l}\text { Benefit sharing } \\
\text { mechanism } \\
\text { operational? }\end{array}$ & $\begin{array}{c}\text { Feedback and } \\
\text { Grievance Redress } \\
\text { Mechanism designed? }\end{array}$ & $\begin{array}{c}\text { Feedback and Grievance } \\
\text { Redress Mechanism } \\
\text { operational? }\end{array}$ \\
\hline Cameroon & Partial & No & Unclear/ambiguous & No \\
\hline Central African Republic & No & No & No & No \\
\hline Côte d'Ivoire & Partial & No & Yes & Partial \\
\hline $\begin{array}{l}\text { Democratic Republic of } \\
\text { Congo }\end{array}$ & Partial & No & Partial & No \\
\hline Ethiopia & Partial & No & Yes & No \\
\hline Gabon & No & No & Yes & No \\
\hline Republic of Congo & Unclear/ambiguous & No & Unclear/ambiguous & No \\
\hline Tanzania & No & No & No & No \\
\hline Zambia & No & No & No & No \\
\hline Bhutan & Unclear/ambiguous & No & No & No \\
\hline Cambodia & No & No & No & No \\
\hline Fiji & Partial & No & Yes & No \\
\hline Indonesia & Yes & No & Yes & No \\
\hline Lao PDR & Partial & No & Yes & No \\
\hline Mongolia & No & No & Partial & No \\
\hline Nepal & Partial & No & Yes & No \\
\hline Papua New Guinea & No & No & Yes & No \\
\hline Philippines & Yes & No & No & No \\
\hline Thailand & No & No & No & No \\
\hline Vietnam & Yes & Partial & Yes & No \\
\hline Bolivia & No & No & No & No \\
\hline Brazil & No & No & Yes & No \\
\hline Colombia & No & No & Yes & No \\
\hline Costa Rica & Yes & No & Yes & Yes \\
\hline Dominican Republic & Partial & No & Partial & No \\
\hline Guyana & No & No & Yes & Unclear/ambiguous \\
\hline Honduras & No & No & Unclear/ambiguous & No \\
\hline Mexico & Yes & Yes & Yes & Yes \\
\hline Nicaragua & Partial & No & Yes & No \\
\hline Peru & No & No & Yes & No \\
\hline Suriname & No & No & Yes & No \\
\hline
\end{tabular}

\section{(c) Country Governance}

Most of the land-based carbon sinks targeted by voluntary and compliance markets are located in conflict-prone countries with poor track records on issues related to human rights, corruption, and adherence to the rule of law. ${ }^{46}$ Using Transparency International's 2020 Corruption Perceptions Index (CPI), an analysis of perceived levels of public sector corruption in the 31 countries reviewed shows that all but two ${ }^{47}$ scored lower than the 50 th percentile mark, ${ }^{48}$ with a total average score (33.5 percent) ${ }^{49}$ equal to the bottom third of country rankings. 
Countries also fare poorly with respect to the rule of law. The World Justice Project's 2020 Rule of Law Index evaluates countries based on eight factors, including constraints on government powers, absence of corruption, open government, fundamental rights, order and security, regulatory enforcement, civil justice, and criminal justice. Using a scoring index of 0 to 1, where 1 indicates the strongest adherence to the rule of law, ${ }^{50}$ only six of the 24 countries with available data scored above 0.5 , with an average score of $0.47 .{ }^{51}$

In the context of rapidly expanding demand for nature-based climate actions, high corruption and weak rule of law could lead to further weakening of benefit-apportionment and distribution processes, including for non-carbon benefits, ${ }^{52}$ while limiting the value of safeguards and the ability of civil society to effectively monitor and enforce these. As seen in abuses triggered by pandemicrelated economic recovery plans, ${ }^{53}$ the combination of weak governance institutions and increased income flows can give rise to more rent-seeking behaviours and increased likelihood of violence, criminalization and land grabs against the poorer and more marginalized segments of society. Without adequate firewalls and benefits, community support for nature-based solutions could waiver over time, potentially jeopardizing the permanence of sequestered carbon ${ }^{54}$ and the hopes of equitable and sustainable outcomes for all.

Table 5: Governance indicators

\begin{tabular}{|c|c|c|}
\hline & Rule of Law & Level of Corruption \\
\hline Country & $\begin{array}{l}\text { Data from WJP Rule of Law Index } 2020 \\
\text { (Scores range from } 0 \text { to } 1 \text {, with } 1 \text { indicating } \\
\text { the strongest adherence to the rule of law) }\end{array}$ & $\begin{array}{l}\text { Transparency International Corruption } \\
\text { Perceptions Index } 2020 \text { (Scores range from } 0-100, \\
\text { with } 0 \text { being the worst and } 100 \text { being the best) }\end{array}$ \\
\hline Cameroon & 0.36 & 25 \\
\hline Central African Republic & Not available & 26 \\
\hline Côte d'Ivoire & 0.46 & 36 \\
\hline Democratic Republic of Congo & 0.34 & 18 \\
\hline Ethiopia & 0.41 & 38 \\
\hline Gabon & Not available & 30 \\
\hline Republic of Congo & Not available & 19 \\
\hline Tanzania & 0.47 & 38 \\
\hline Zambia & 0.45 & 33 \\
\hline Bhutan & Not available & 68 \\
\hline Cambodia & 0.33 & 21 \\
\hline Fiji & Not available & Not available \\
\hline Indonesia & 0.53 & 37 \\
\hline Lao PDR & Not available & 29 \\
\hline Mongolia & 0.53 & 35 \\
\hline Nepal & 0.53 & 33 \\
\hline Papua New Guinea & Not available & 27 \\
\hline Philippines & 0.47 & 34 \\
\hline Thailand & 0.51 & 36 \\
\hline Vietnam & 0.49 & 36 \\
\hline Bolivia & 0.38 & 31 \\
\hline Brazil & 0.52 & 38 \\
\hline Colombia & 0.5 & 39 \\
\hline Costa Rica & 0.68 & 57 \\
\hline Dominican Republic & 0.48 & 28 \\
\hline Guyana & 0.5 & 41 \\
\hline Honduras & 0.4 & 24 \\
\hline
\end{tabular}




\begin{tabular}{|l|c|c|}
\cline { 2 - 3 } \multicolumn{1}{c|}{} & \multicolumn{1}{c|}{ Rule of Law } & Level of Corruption \\
\hline Country & $\begin{array}{c}\text { Data from WJP Rule of Law Index 2020 } \\
\text { (Scores range from 0 to 1, with 1 indicating } \\
\text { the strongest adherence to the rule of law) }\end{array}$ & $\begin{array}{c}\text { Transparency International Corruption } \\
\text { Perceptions Index 2020 (Scores range from 0 - 100, } \\
\text { with 0 being the worst and 100 being the best) }\end{array}$ \\
\hline Mexico & 0.44 & 31 \\
\hline Nicaragua & 0.39 & 22 \\
\hline Peru & 0.5 & 38 \\
\hline Suriname & 0.5 & 38 \\
\hline
\end{tabular}

\section{Community Rights and Voluntary Certification Standards}

Several voluntary certification standards and compliance mechanisms have emerged in recent years to bolster the integrity, equity, and fairness of market-based transactions. While some offer better consideration of Indigenous Peoples', local communities' and Afro-descendant Peoples' rights, none of the reviewed initiatives and frameworks fully address the risks posed by surging interest in natural climate solutions. Analysis of six leading voluntary certification standards (see Table 6 below) show variable protections for communities' rights, particularly with respect to efforts to monitor, protect, and uphold their land and human rights.

Only two standards (the Climate, Community and Biodiversity Standards (CCBS) and the Land Rights Standard) require acknowledgement of the rights of Indigenous Peoples, local communities, and Afro-descendant Peoples as established under international law, as well as effective recognition and respect for their statutory and customary tenure and resource rights. ${ }^{55}$ Others, such as Plan Vivo, ART-TREES and the Verified Carbon Standard (VCS), partially address this criterion. For instance, Plan Vivo requires project interventions to demonstrate that affected smallholders and/ or community groups "have clear, stable land tenure, either via ownership, or user rights", but does not include explicit mention of their customary rights. ${ }^{56}$ On the other hand, the VCS stipulates that project ownership must be demonstrated and customary tenure and access rights identified, but there is no specified obligation to respect rights that have not been legally recognized. None of the reviewed standards explicitly call for the recognition of community carbon rights.

With respect to the full and effective participation of communities in decisions that may directly or indirectly affect their rights and their social, economic, and environmental wellbeing, only 3 of the reviewed standards (CCBS, Plan Vivo, and Gold Standard) provide concrete indicators or requirements in this regard, including robust provisions relating to FPIC. Moreover, only 1 (Plan Vivo) mandates the development of benefit-sharing plans. Four of the six standards (CCB, Plan Vivo, Gold Standard, and VCS) require the establishment of a feedback and grievance redress mechanism, although the rigorousness of this requirement varies.

Finally - and perhaps most crucially - only two of the standards (CCBS and Gold Standard) include requirements for the establishment of baselines for community wellbeing, along with impact monitoring and reporting using prescribed substantive indicators. Like ERR credits, which are subject to highly rigorous measurement, monitoring, reporting, and verification requirements, the realization of social and environmental benefits also requires an assessment of baseline conditions, clear goals, and measurable, time-bound progress indicators to monitor and support actions towards desired results. Failure to imbed carbon and non-carbon benefits in the context of community life plans and the pursuit of self-determined priorities ultimately reduces the value of safeguards and benefit sharing plans and the potential for fair, equitable, and sustainable climate actions.

By comparison, analysis of the two multilateral REDD+ funding mechanisms - the Green Climate Fund's REDD+ results-based payments pilot programme (GCF RBP Pilot) and the FCPF's Carbon Fund - reveals that consideration of communities' rights by these institutions is similarly variable. The Carbon Fund recognizes communities' customary land and resource rights and requires that 
Table 6: Summary of voluntary certification standards and institutional requirements

\begin{tabular}{|c|c|c|c|c|c|c|}
\hline & $\begin{array}{c}\text { Is there effective } \\
\text { legal recognition } \\
\text { of communities' } \\
\text { customary land } \\
\text { and resource } \\
\text { rights? }\end{array}$ & $\begin{array}{l}\text { Is there explicit } \\
\text { legal recognition } \\
\text { of communities' } \\
\text { rights to carbon? }\end{array}$ & $\begin{array}{l}\text { Is the full } \\
\text { and effective } \\
\text { participation of } \\
\text { IP / LC / ADPs* } \\
\text { mandated? Are } \\
\text { there robust } \\
\text { requirements } \\
\text { for FPIC? }\end{array}$ & $\begin{array}{l}\text { Is a formal } \\
\text { benefit-sharing } \\
\text { mechanism } \\
\text { required? }\end{array}$ & $\begin{array}{l}\text { Is a formal } \\
\text { feedback and } \\
\text { grievance } \\
\text { redress } \\
\text { mechanism } \\
\text { required? }\end{array}$ & $\begin{array}{l}\text { Are there robust } \\
\text { provisions for } \\
\text { measurement, } \\
\text { monitoring, } \\
\text { reporting, and } \\
\text { verification with } \\
\text { respect to rights } \\
\text { and safeguards? }\end{array}$ \\
\hline $\begin{array}{l}\text { ART/TREES } \\
\text { (information } \\
\text { from TREES } \\
\text { Draft 2.0) }\end{array}$ & Limited & No & Limited & No & No & Limited \\
\hline $\begin{array}{l}\text { Climate, } \\
\text { Community } \\
\text { and Biodiversity } \\
\text { Standards } \\
\text { (version 3.1) }\end{array}$ & Yes & No & Yes & No & Yes & Yes \\
\hline $\begin{array}{l}\text { The Plan Vivo } \\
\text { Standard (2013) }\end{array}$ & Limited & No & Yes & Yes & Yes & Limited \\
\hline $\begin{array}{l}\text { Gold Standard } \\
\text { for the Global } \\
\text { Goals (version } \\
1.2 \text { ) }\end{array}$ & Yes & No & Yes & No & Yes & Yes \\
\hline $\begin{array}{l}\text { Verified Carbon } \\
\text { Standard } \\
\text { (version 4.1) }\end{array}$ & Limited & No & Limited & No & Yes & No \\
\hline $\begin{array}{l}\text { VCS } \\
\text { Jurisdictional } \\
\text { and Nested } \\
\text { REDD+ (Scenario } \\
\text { 3 Requirements) } \\
\text { (version 4.0) }\end{array}$ & Limited & No & Limited & Yes & Yes & No \\
\hline $\begin{array}{l}\text { Carbon Fund } \\
\text { (Methodological } \\
\text { Framework) }\end{array}$ & Yes & Limited & Limited & Yes & Yes & Yes \\
\hline $\begin{array}{l}\text { GCF } \\
\text { (Environmental } \\
\text { and Social Policy, } \\
\text { Indigenous } \\
\text { Peoples Policy, } \\
\text { and Terms of } \\
\text { reference for the } \\
\text { pilot programme } \\
\text { for REDD+ } \\
\text { results-based } \\
\text { payments) }\end{array}$ & Limited & No & Yes & No & Yes & Limited \\
\hline
\end{tabular}

* IP / LC / ADPs = Indigenous Peoples, Local Communities and Afro-descendant Peoples

${ }^{* *}$ A detailed version of Table 6 is available for consultation online.

Program Entities demonstrate their ability to transfer the title to emission reductions. However, the Carbon Fund's Methodological Framework does not explicitly endorse FPIC. ${ }^{57}$ On the other hand, the Carbon Fund does require a formal benefit-sharing mechanism and grievance redress mechanism, and includes provisions for monitoring, reporting, and verification with respect to rights and safeguards. The GCF RBP Pilot provides limited protections for communities' customary land and resource rights, although it does include requirements for the full and effective participation of Indigenous Peoples and local communities, as well as for access to grievance redress mechanisms. Nevertheless, the GCF RBP Pilot does not require the establishment of a formal benefit-sharing mechanism, and fund disbursements are not contingent on performance against safeguards criteria once programmes have been accepted. 


\section{Conclusion and Recommendations}

The findings in this report demonstrate that few countries have established the necessary conditions for fair, effective, and transparent carbon or REDD+ transactions. Combined with the fact that at least half of the lands customarily held by communities within analyzed countries have yet to be legally recognized by governments, the limited assurances provided by the current legal and regulatory architecture leaves communities with no effectual standing in the global surge to control terrestrial carbon sinks. Overall, few countries explicitly recognize community carbon rights, and even fewer have tested the operational and political feasibility of established rules. The limited attention to community rights thus lies in stark contrast to the substantial investments that have been made so far to measure the carbon located in communities' lands - a situation made worse by the general lack of safeguards and benefit-sharing mechanisms.

To be fair, transparent and effective, the process by which carbon and other resource rights are determined and formalized must itself be aligned with international human rights laws, including recognition of communities' customary land and resource rights, and their rights to selfdetermination; free, prior and informed consent; due process; and compensation. As recognized in the safeguard requirements identified in the 2010 Cancun Agreements, countries must have in place transparent and effective national forest governance structures that allow for: (i) the recognition of community land and resource rights and the establishment of operational feedback and grievance redress mechanisms; (ii) respect for the knowledge and rights of Indigenous Peoples and local communities; and (iii) the full and effective participation of Indigenous Peoples and local communities in the design and implementation of ERRs and associated benefit sharing plans. Finally, local peoples must have assurance that their customary land and resource rights will be effectively upheld and enforced against possible violations. ${ }^{58}$

Without explicit recognition of communities' land and carbon rights, including enforcement of their rights to free, prior and informed consent and to define and negotiate the terms of their engagement, including any benefits or payments arising from the sale of emission reductions credits or carbon offsets, the acceleration of jurisdictional approaches risks exacerbating the myriad challenges they already face, namely: (i) exclusion from land use decisions; (ii) increasing land grabs and efforts to capture associated rents; (iii) continued dismissal of local social-ecological realities and the self-determined priorities of affected communities; and (iv) the ever-growing threats of human rights violations, criminalization, and conflicts.

These risks are further magnified by the fact that most of the world's tropical and subtropical countries with a high potential for nature-based solutions are also amongst the weakest in terms of transparency, accountability, and effective application of the rule of law. From the perspective of public or private investors, the pursuit of nature-based solutions in poorly governed countries carries additional levels of risks that can largely be mitigated by ensuring that the rights and contributions of those who effectively own and manage the lands and forests targeted by emission reduction schemes are duly recognized and compensated.

Finally, while voluntary certification standards for carbon-based transactions have been touted as effective risk mitigation strategies for communities and the environment alike, this review identified a number of limitations that could seriously undermine their value as safeguard instruments. Though most include some combination of provisions relating to human rights, the recognition of communities' land tenure and resource rights, engagement and participation, benefit sharing, and channels for feedback and grievance redress, they largely fail to provide robust mechanisms for the measurement, monitoring, reporting, and verification of these elements. In the absence of more transparent and effective implementation frameworks, the rights of Indigenous Peoples, local communities, and Afro-descendant Peoples, and their ability to effectively participate and engage in these processes, will remain doubtful.

To mitigate such risks, voluntary standards, jurisdictional initiatives, and dedicated market schemes 
engaged in land-based emission reductions and carbon offsets should commit to three underlying principles:

1. Insist on "quality at entry" to ensure that all emission reductions and offset projects and jurisdictional proposals explicitly explain and provide assurance of how Indigenous and community land and carbon rights (whether legally recognized or not) will be recognized and respected.

2. Uphold community rights to free, prior and informed consent and the ability to "opt-out" of emission reduction agreements (at project or jurisdictional levels) that do not conform to their rights and priorities, ensuring always that their rights will be protected through direct access to an independent feedback and grievance redress mechanism.

3. Ensure full and effective involvement of communities in the design and implementation of benefit-sharing mechanisms to ensure fair and transparent compensation for their role and contributions to GHG mitigation.

Not meeting these conditions risks irreparable harm to local peoples, their forests, and global efforts to address the climate crisis. At the same time, mandating these steps would incentivize governments to advance the recognition of rights and strengthen governance across tropical forest areas - an essential stepping stone for the success of all nature-based solutions and development outcomes at scale.

${ }^{1}$ REDD+ stands for "Reducing emissions from deforestation and forest degradation and the role of conservation, sustainable management of forests and enhancement of forest carbon stocks in developing countries."

${ }^{2}$ Rights and Resources Initiative. 2018. Uncertainty and Opportunity: The Status of Forest Carbon Rights and Governance Frameworks in Over Half of the World's Tropical Forests. RRI: Washington, DC. 4. Available at: https:// rightsandresources.org/publication/uncertainty-opportunity-status-forest- carbon-rights-governance-frameworks-halfworlds-tropical-forests/. To date, 11 countries have signed Emission Reductions Payment Agreements with the Forest Carbon Partnership Facility, with a total contract value in excess of $\$ 550$ million. See: World Bank. 2021. Press Release: Madagascar Signs Landmark Agreement with the World Bank to Reduce Poverty, Deforestation and Carbon Emissions. Available at: https://www.worldbank.org/en/news/ press-release/2021/02/05/madagascar-signs-landmark-agreementwith-the-world-bank-to-reduce-poverty-deforestation-and-carbon-emissions.

${ }^{3}$ Notably, as of 2019, approximately half the countries that had submitted Nationally Determined Contributions under the Paris Agreement indicated that they planned to participate in carbon markets or other international "cooperative approaches" in meeting their targets. See: Hood, Christina. 2019. Completing the Paris 'Rulebook': Key Issues. Center for Climate and Energy Solutions: Arlington, VA. Available at: https://www.c2es. org/document/completing-the-parisrulebook-key-article-6-issues/; CIEL. 2021. Rights, Carbon, Caution: Upholding Human Rights under Article 6 of the Paris Agreement. CIEL: Washington, DC. Available at: https://www.ciel.org/reports/rights-carbon-caution/\#: :text=PublicationRights $\% 2$ C 20 Carbon\%2C\%20Caution\%3A\%20Upholding\%20Human\%20Rights\%20under\%20Article\%206,Read\%20 the\%20full\%20report.\&text=In\%20so\%20 doing\%2C\%20they\%20are,adverse\%20impacts\%20of\%20that\%20action.

${ }^{4}$ UN Climate. 2020. “UN Climate Press Release: Commitments to Net Zero Double in Less Than a Year." Available at: https://unfccc.int/news/commitments-to-net-zero-double-in-less-than-a-year; Geck, Marshall. 2020. “Seven Major Companies That Committed to Net Zero Emissions in 2020." Principles for Responsible Investment Blog. Available at: https://www.unpri.org/pri-blog/seven-major-companies-that-committed-to-net-zero- emissions-in-2020/6909.article.

${ }^{5}$ Taskforce on Scaling Voluntary Carbon Markets. https://www.iif.com/tsvcm.

${ }^{6}$ For RRI, the term 'Indigenous Peoples' follows the definition or 'statement of coverage' contained in the International Labor Organization Convention on Indigenous and Tribal Peoples in Independent Countries. Therefore, it includes: peoples who identify themselves as 'indigenous;' tribal peoples whose social, cultural, and economic conditions distinguish them from other sections of the national community, and whose status is regulated wholly or partially by their own customs or traditions or by special laws or regulations; traditional peoples not necessarily called indigenous or tribal but who share the same characteristics of social, cultural, and economic conditions that distinguish them from other sections of the national community, whose status is regulated wholly or partially by their own customs or traditions, and whose livelihoods are closely connected to ecosystems and their goods and services. While RRI recognizes that all people should enjoy equal rights and respect regardless of identity, it is strategically important to distinguish Indigenous Peoples from other stakeholders. They have a distinct set of rights linked to their social, political, and economic situation as a result of their ancestry and stewardship of lands and resources vital to their well-being. 
${ }^{7}$ Recognizing that local communities are not formally defined under international law, RRI considers that they encompass communities that do not self-identify as Indigenous but who share similar characteristics of social, cultural, and economic conditions that distinguish them from other sections of the national community; whose status is regulated wholly or partially by their own customs or traditions, who have long-standing, culturally constitutive relations to lands and resources; and whose rights are held collectively.

${ }^{8}$ As per the Declaration of Santiago of 2000, the States of the Americas defined Afro-descendant as "the person of African origin who lives in the Americas and in the region of the African Diaspora as a result of slavery, who have been denied the exercise of their fundamental rights." (See: The Durban Conference and Program of Action; The International Decade for People of African Descent https://www.un.org/en/durbanreview2009/pdf/DDPA_full_text.pdf). In Latin America and the Caribbean, constitutional and legal recognition of Afro-descendants' collective tenure rights is based on their special cultural, ethnic, and spiritual relationship with land.

${ }^{9}$ RRI. 2020. Estimated area of land and territories of Indigenous Peoples, local communities and Afro-descendants where their rights are not recognized. Rights and Resources Initiative; Washington DC. Available at: https://rightsandresources. org/publication/estimate-of-the-area-of-land-and-territories-of-indigenous-peoples-local-communities-and-afrodescendants-where-their-rights-have-not-been-recognized/ [Area Estimates].

${ }^{10}$ The countries covered within this study include in Africa: Cameroon, Central African Republic, Côte d'Ivoire, Democratic Republic of Congo, Ethiopia, Gabon, Republic of Congo, Tanzania, and Zambia; in Asia: Bhutan, Cambodia, Fiji, Indonesia, Lao People's Democratic Republic, Mongolia, Nepal, Papua New Guinea, Philippines, Thailand, and Vietnam; and in Latin America: Bolivia, Brazil, Colombia, Costa Rica, Dominican Republic, Guatemala, Guyana, Honduras, Mexico, Nicaragua, Peru, and Suriname.

${ }^{11}$ Food and Agriculture Organization of the United Nations. 2020. Global Forest Resources Assessment 2020, $136-142$. FAO, Rome. Available at: http://www.fao.org/documents/card/en/c/ca9825en.

${ }^{12}$ McKinsey \& Company and World Economic Forum. 2021. Consultation: Nature and Net Zero. World Economic Forum: Cologny/Geneva, Switzerland. Available at: https://www.mckinsey.com/business-functions/sustainability/our-insights/ why-investing-in-nature-is-key-to-climate-mitigation.

13 Ibid.: 13.

${ }^{14}$ Based on available data regarding the extent of community lands with and without legal recognition for 21 of the 31 countries analyzed. These countries are: Bolivia, Brazil, Cambodia, Cameroon, Central African Republic, Colombia, Cost Rica, Democratic Republic of Congo, Gabon, Guyana, Indonesia, Lao PDR, Mexico, Nepal, Peru, Philippines, Republic of Congo, Suriname, Tanzania, Thailand, Zambia (RRI 2020a: supra note 8).

${ }^{15}$ As per Article 4 of the Paris Agreement.

${ }^{16}$ Streck, Charlotte and Moritz von Unger. Carbon \& Climate Law Review Vol. 10, No. 3, Special Issue on Carbon Rights (2016), 178-189: 178.

${ }^{17}$ Knox, Anna et al. 2012. Forest Carbon Rights Guidebook: A Tool for Framing Legal Rights to Carbon Benefits Generated through REDD+ Programming. USAID, Burlington, Vermont. Available at: https://www.land-links.org/wp-content/ uploads/2016/09/USAID_Land_Tenure_PRRGP_Forest_Carbon_Rights_Guidebook_011314.pdf: 7.

${ }^{18}$ Streck, Charlotte. 2020. "Who Owns REDD+? Carbon Markets, Carbon Rights and Entitlements to REDD+ Finance." Forests 11:9: 959, available at: https://www.mdpi.com/1999-4907/11/9/959.

${ }^{19}$ RRI 2020a: 11.

${ }^{20}$ Chomba, Susan Chomba et al. 2016. Roots of inequity: How the implementation of REDD+ reinforces past injustices. Land Use Policy 50 202-213: 211; Larson, Anne M. and Jenny Springer. 2016. Recognition and Respect for Tenure Rights Natural Resource Governance Framework Conceptual Paper. IUCN, CEESP \& CIFOR: 8.

${ }^{21}$ Government of the Republic of Zambia. 2015. The Forest Act No. 4 of 2015 at Section 3. Available at http://www. parliament.gov.zm/sites/default/files/documents/acts/The\%20Forest\%20Act\%202015.pdf.

${ }^{22}$ FAO. 2019. Scaling up community participation in forest management through REDD+ in Zambia: 2. Available at: http:// www.fao.org/3/ca2993en/CA2993EN.pdf.

${ }^{23}$ BioCarbon Partners (BCP). 2019. Announcement! Local communities secure Zambia's first carbon rights. Available at http://blog.biocarbonpartners.com/announcement-local-communities-secure-zambias-first-carbon-rights/.

${ }^{24}$ BioCarbon Partners. Luangwa Community Forests Project. Available at: https://biocarbonpartners.com/impacts/ luangwa-community-forests-project/.

25 "Zambia sets global benchmark for community forest conservation." September 10, 2020, Financial Post. Available at: https://financialpost.com/pmn/press-releases-pmn/business-wire-news-releases-pmn/zambia-sets-global-benchmarkfor-community-forest-conservation. 
${ }^{26}$ See Article 41 (I) (A) Brazilian Forestry Code and Article 1.228 Brazilian Civil Code. The legal understanding is corroborated by Loft, Lasse et al. 2015. Taking Stock of Carbon Rights in REDD+ Candidate Countries: Concept Meets Reality. Forests 6(4), 1041. Available at: http://www.mdpi.com/1999-4907/6/4/1031.

${ }^{27}$ See State Law ${ }^{0} 1.917$ of April 17, 2008, which establishes that the state is the beneficiary or holder of carbon credits produced in the scope of emission reduction programs (Article 19).

${ }^{28}$ Instituto Socioambiental (ISA). 2021. Terras indígenas no Brasil. Available at: https://terrasindigenas.org.br/.

${ }^{29}$ Neepes/ENSP/Fiocruz. 2021. Mapa de conflitos envolvendo injustiça ambiental e saúde no Brasil. Available at: http:// mapadeconflitos.ensp.fiocruz.br/.

${ }^{30}$ Based on available data regarding the extent of community lands with and without legal recognition for 21 of the 31 countries analyzed. These countries are: Bolivia, Brazil, Cambodia, Cameroon, Central African Republic, Colombia, Cost Rica, Democratic Republic of Congo, Gabon, Guyana, Indonesia, Lao PDR, Mexico, Nepal, Peru, Philippines, Republic of Congo, Suriname, Tanzania, Thailand, Zambia (RRI. Area Estimates, supra note 8).

${ }^{31}$ RRI 2020a: 19.

${ }^{32}$ For example, of the FCPF countries, the vast majority do have legislation securing community tenure to forests, despite limited recognition of IPLCAD lands overall. See RRI 2020a.

${ }^{33}$ RRI 2020a: 10. In the Democratic Republic of Congo, laws relating to Forest Code of the Democratic Republic of Congo Law N 011/2002; Decree No. 14/018; Law 14/003 of February 11th, 2014 in Relation to the Conservation of Nature.

${ }^{34}$ Kengoum, Félicien, Pham Thu Thuy and Denis Jean Sonwa. 2020. "A decade of REDD+ in a changing political environment in the Democratic Republic of Congo." CIFOR Info Brief No. 318: 7. Available at: https://www.cifor.org/ publications/pdf files/infobrief/7893-infobrief.pdf.

${ }^{35}$ RRI 2020a; Walker, W. et al. 2020. The role of forest conversion, degradation, and disturbance in the carbon dynamics of Amazon indigenous territories and protected areas. PNAS. Available at: https://www.researchgate. net/publication/338858779; Blackman, Allen, Leonardo Corral, Eirivelthon Santos Lima, and Gregory P. Asner. 2017. Titling indigenous communities protects forests in the Peruvian Amazon. PNAS, 114 (16) 4123-4128; Ceddia, Graziano M., U. Gunter, and A. Corriveau-Bourque. 2015. Land tenure and agricultural expansion in Latin America: The role of Indigenous Peoples' and local communities' forest rights. Global Environmental Change, 35, 316-322. Wehkamp, J., N. Koch, S. Lübbers, and S. Fuss. 2018. Governance and deforestation-a meta-analysis in economics. Ecological Economics, 144, 214-227; Blackman, Allen, and Peter Veit. 2018. Titled Amazon Indigenous Communities Cut Forest Carbon Emissions. Ecological Economics 153: 56-57; Ding, H., P. Veit, A. Blackman, E. Gray, K. Reytar, J. C. Altamirano. 2016. Climate Benefits, Tenure Costs. The Economic Case for Securing Indigenous Land Rights in the Amazon. Washington, DC: World Resources Institute. Nolte, Christoph, Arun Agrawal, Kirsten M. Silvius, and Britaldo S. Soares-Filho. 2016. Governance regime and location influence avoided deforestation success of protected areas in the Brazilian Amazon. PNAS, 110 (13) 4956-4961; Stevens, C. et al. 2014. Securing Rights, Combating Climate Change: How strengthening community forest rights mitigates climate change. Washington, DC: RRI and WRI. https:// rightsandresources.org/wp-content/uploads/Securing-Rights-Combating-Climate-Change.pdf.

${ }^{36}$ Rainforest Foundation Norway. 2021. Falling Short: Donor Funding for Indigenous Peoples and Local Communities to Secure Tenure Rights and Manage Forests in Tropical Countries (2011-2020). Rainforest Foundation Norway, Oslo. Available at: https://d5i6is0eze552.cloudfront.net/documents/Publikasjoner/Andre-rapporter/RFN_Falling_short_2021. pdf?mtime $=20210412123104$.

${ }^{37}$ Rights and Resources Initiative. 2020b. "The Opportunity Framework: Identifying Opportunities to Invest in Securing Collective Tenure Rights in the Forest Areas of Low and Middle-Income Countries." RRI, Washington DC. Available at: https://rightsandresources.org/wp-content/uploads/2020/09/Opp-Framework-Final.pdf; and Rights and Resources Initiative and Tenure Facility. 2021. "Scaling-Up the Recognition of Indigenous and Community Land Rights: Opportunities, Costs and Climate Implications Technical Report." RRI, Washington, DC. Available at: https:// rightsandresources.org/publication/scaling-up-the-recognition-of-indigenous-and-community-land-rights/.

${ }^{38}$ Arneth, A., et al. 2020. "Climate Change and Land Summary for Policymakers." IPCC. https://www.ipcc.ch/srccl/chapter/ summary-for-policymakers; Diaz, S., et al. 2019. "Report of the Plenary of the Intergovernmental Science-Policy Platform on Biodiversity and Ecosystem Services." IPBES. Available at: https://www.ipbes.net/sites/default/files/ipbes 710 add.1 en 1.pdf; Shukla, P.R., et al. 2019. "Technical Summary." IPCC. Available at: https://www.ipcc.ch/site/assets/ uploads/sites/4/2020/07/03_Technical-Summary-TS_V2.pdf.

${ }^{39}$ Bhutan, Cameroon, Central African Republic, Colombia, Costa Rica, Cote d'Ivoire, Dominican Republic, Ethiopia, Fiji, Gabon, Indonesia, Lao PDR, Mongolia, Mexico, Nepal, Nicaragua, Papua New Guinea, Peru, Philippines, Republic of Congo, Suriname, Thailand, Vietnam, and Zambia.

${ }^{40}$ The countries that have designed benefit sharing mechanisms are: Costa Rica, Indonesia, Mexico, Philippines, and Vietnam. Eight more countries have partially-designed benefit sharing mechanisms: Cameroon, Democratic Republic of Congo, Dominican Republic, Ethiopia, Fiji, Lao PDR, Nepal, and Nicaragua. For a further two countries, the existence of a benefit sharing mechanism was unclear/ambiguous: Bhutan and Republic of Congo. 
${ }^{41}$ Joint FCPF/UN-REDD Programme Guidance Note for REDD+ Countries: 4.

42 UN REDD and FCPF. 2015. Joint FCPF/UN-REDD Programme Guidance Note for REDD+ Countries: Establishing and Strengthening Grievance Redress Mechanisms: 3 - 4.

${ }^{43}$ Countries with fully-designed FGRMs: Brazil, Colombia, Costa Rica, Ethiopia, Fiji, Gabon, Guyana, Indonesia, Lao PDR, Mexico, Nepal, Nicaragua, Papua New Guinea, Peru, Suriname, and Vietnam. Countries with partially-designed FGRMs: Democratic Republic of Congo, Dominican Republic, and Mongolia. Operationalized: Costa Rica and Mexico.

${ }^{44}$ Costa Rica.

${ }^{45}$ Rights and Resources Initiative. 2018. Uncertainty and Opportunity: The Status of Forest Carbon Rights and Governance Frameworks in Over Half of the World's Tropical Forests. RRI: Washington, DC: 14.

${ }^{46}$ Aled Williams \& Kendra Dupuy, "Will REDD+ Safeguards Mitigate Corruption? Qualitative Evidence from Southeast Asia" 2018 Journal of Development Studies 55(3): 2.

${ }^{47}$ Bhutan received a score of 68, while Costa Rica received a score of 57.

${ }^{48}$ Bolivia, Brazil, Cambodia, Cameroon, Central African Republic, Colombia, Democratic Republic of Congo, Dominican Republic, Ethiopia, Gabon, Guyana, Honduras, Indonesia, Lao PDR, Mexico, Mongolia, Nepal, Nicaragua, Papua New Guinea, Peru, Philippines, Republic of Congo, Suriname, Tanzania, Thailand, Vietnam, and Zambia. Data for Fiji was not available.

${ }^{49}$ Data for Fiji was not available.

502020 WJP Rule of Law Index.

${ }^{51}$ Average score for the countries for which data was available.

${ }^{52}$ Costenbader, John (Ed.). 2009. Legal Frameworks for REDD: Design and Implementation at the National Level. IUCN, Gland, Switzerland: 57.

${ }^{53}$ For example, see Greenfield, Patrick. "Indigenous peoples face rise in rights abuses during pandemic, report finds." The Guardian, February, 2021. Available at: https://www.theguardian.com/environment/2021/feb/18/indigenouspeoples-face-rise-in-rights-abuses-during-covid-pandemic-report-aoe.

${ }^{54}$ Costenbader 2009: 57.

${ }^{55}$ Anja Kollmuss, Helge Zink \& Clifford Polycarp. 2008. Making Sense of the Voluntary Carbon Market: A Comparison of Carbon Offset Standards. WWF Germany: vi. Available at: https://www.globalcarbonproject.org/global/pdf/ WWF_2008_A\%20comparison\%20of\%20C\%20offset\%20Standards.pdf.

${ }^{56}$ The Plan Vivo Standard for Community Payments for Ecosystem Services Programmes at 1.1.

${ }^{57}$ While the World Bank's ESS7 on Indigenous Peoples/Sub-Saharan African Historically Underserved Traditional Local Communities does address FPIC, it only requires that it be obtained in a limited set of circumstances (namely, when a project will: (a) have adverse impacts on land and natural resources subject to traditional ownership or under customary use or occupation; (b) cause relocation of Indigenous Peoples/ Sub-Saharan African Historically Underserved Traditional Local Communities from land and natural resources subject to traditional ownership or under customary use or occupation; or (c) have significant impacts on Indigenous Peoples/Sub-Saharan African Historically Underserved Traditional Local Communities' cultural heritage that is material to the identity and/or cultural, ceremonial, or spiritual aspects of the affected Indigenous Peoples/ Sub-Saharan African Historically Underserved Traditional Local Communities' lives).

${ }^{58}$ NYDF Assessment Partners. 2018. Improving Governance to Protect Forests: Empowering People and Communities, Strengthening Laws and Institutions - New York Declaration on Forests Goal 10 Assessment Report: 40. Available at: https://www.climatefocus.com/sites/default/files/NYDF\%20report\%202018_0.pdf. 


\section{About the Rights and Resources Initiative}

The Rights and Resources Initiative is a global Coalition of 21 Partners and more than 150 rightsholders organizations and their allies dedicated to advancing the forestland and resource rights of Indigenous Peoples, Afro-descendant Peoples, local communities, and the women within these communities. Members capitalize on each other's strengths, expertise, and geographic reach to achieve solutions more effectively and efficiently. RRI leverages the power of its global Coalition to amplify the voices of local peoples and proactively engage governments, multilateral institutions, and private sector actors to adopt institutional and market reforms that support the realization of their rights and self-determined development. By advancing a strategic understanding of the global threats and opportunities resulting from insecure land and resource rights, RRI develops and promotes rights-based approaches to business and development and catalyzes effective solutions to scale rural tenure reform and enhance sustainable resource governance.

RRI is coordinated by the Rights and Resources Group, a non-profit organization based in Washington, DC. For more information, please visit www.rightsandresources.org.

\section{PARTNERS}
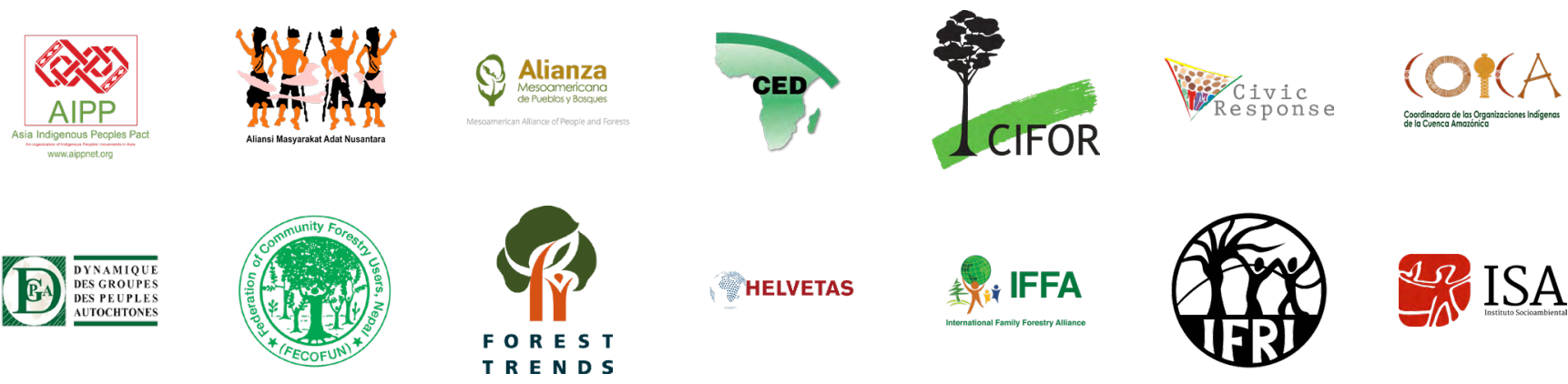

Melvetas
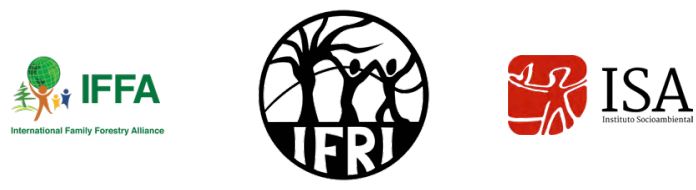

路 Landesa
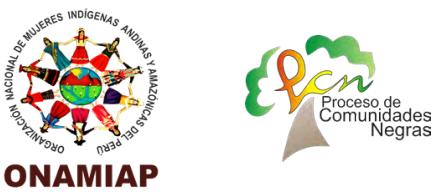

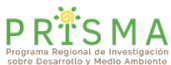

है RECOFTC
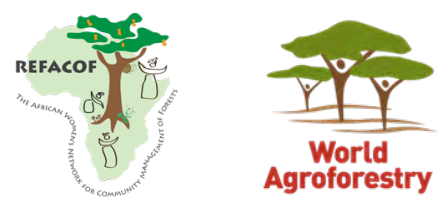

\section{SPONSORS}
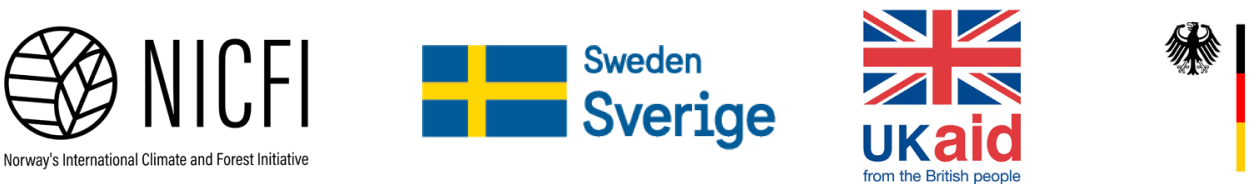

Federal Ministry

for Economic Cooperation

and Development
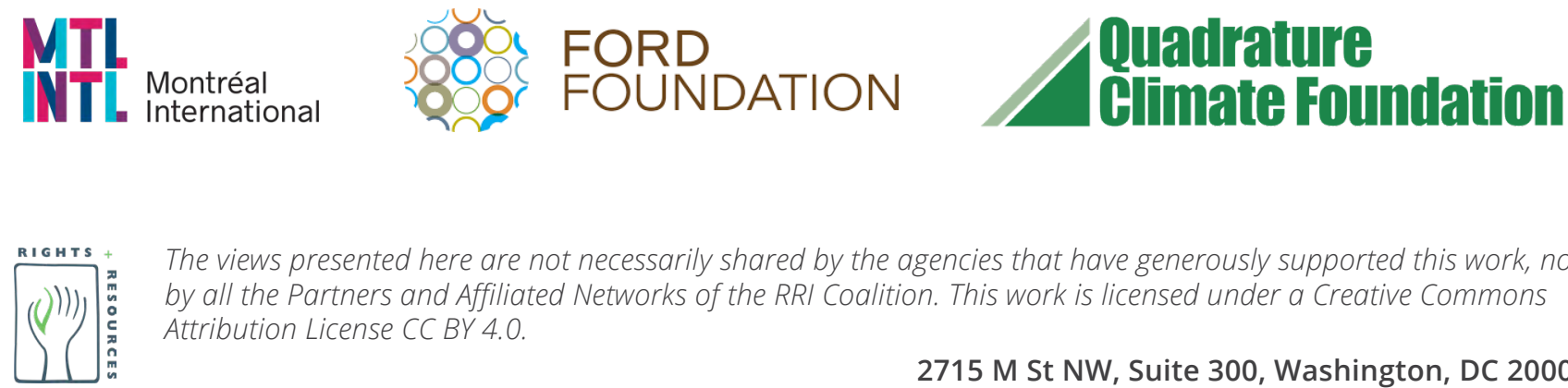

The views presented here are not necessarily shared by the agencies that have generously supported this work, nor by all the Partners and Affiliated Networks of the RRI Coalition. This work is licensed under a Creative Commons Attribution License CC BY 4.0. 